\title{
Pisces, Perciformes, Cichlidae, Laetacara dorsigera (Heckel, 1840): Distribution extension and first record for Uruguay River basin, and state of Rio Grande do Sul, southern Brazil
}

\author{
Luis Esteban Krause Lanés ${ }^{1 *}$, Leonardo Maltchik ${ }^{1}$ and Carlos Alberto S. de Lucena ${ }^{2}$ \\ 1 Universidade do Vale do Rio dos Sinos, Laboratório de Ecologia e Conservação de Ecossistemas Aquáticos (LECEA). Avenida Unisinos 950, Bairro \\ Cristo Rei. CEP 93022-000. São Leopoldo, RS, Brazil. \\ 2 Museu de Ciências e Tecnologia da Pontifícia Universidade Católica do Rio Grande do Sul, Laboratório de Ictiologia. Avenida Ipiranga 6681, \\ prédio 40. CEP 90619-900. Porto Alegre, RS, Brazil. \\ * Corresponding author. E-mail: lelanes@gmail.com
}

\begin{abstract}
The present study records for the first time the small cichlidae fish Laetacara dorsigera (Heckel, 1840) at Uruguay River basin and state of Rio Grande do Sul, southern Brazil, previously known from Amazon, Paraná and Paraguay River basins. Although the ichthyofauna of Uruguay River basin is relatively well known, this record suggests that there are still unexplored environments, such as wetlands, where there may be species not yet reported, and found in other hydrographic systems.
\end{abstract}

The South American cichlid genus Laetacara Kullander, a component of the tribe Cichlasomatini, subfamily Cichlinae (Smith et al. 2008; López-Fernández et al. 2010), is characterized by small size (max. SL $110 \mathrm{~mm}$ ), and comprises currently six species [L. dorsigera, L. flavilabris (Cope, 1870), L. thayeri (Steindachner, 1875), L. curviceps (Ahl, 1923), L. fulvipinnis Staeck and Schindler, 2007 and L. araguaiae Ottoni and Costa, 2009)] distributed in Argentina, Brazil, Ecuador, Paraguay, Peru and Venezuela (Kullander 1986; Casciotta 1998; Staeck and Schindler 2007; Ottoni and Costa 2009; Ottoni et al. 2009). Currently the genus is diagnosed by a single synapomorphy based on the morphology of the hyoid, consisting of a deep notch on the dorsal margin of the anterior cerotohyal (Kullander 1986: Figure 149; Kullander 1998). Its monophyly was recently confirmed by molecular analysis (Musilová et al. 2008).

Laetacara dorsigera (Heckel, 1840) (Figure 1) was recently re-described by Ottoni and Costa (2009), and

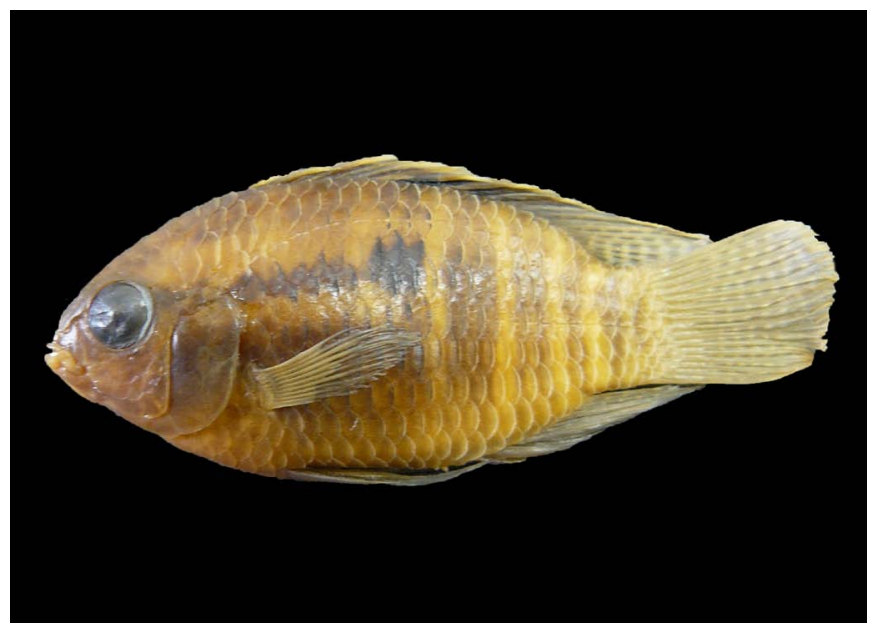

FIGURE 1. Female of Laetacara dorsigera, MCP 44511, $37.3 \mathrm{~mm} \mathrm{SL}$, captured in Uruguay River basin, state of Rio Grande do Sul, southern Brazil. the known distribution of the species, whose type locality is Villa Maria, Paraguay, Paraguay River basin, include Amazon River basin, in the Guaporé River drainage, Paraná River basin, in the Paraguay River drainage in Brazil and Paraguay, and middle Paraná River drainage in Argentina (Kullander 2003) (Figure 2A).

An adult female of $L$. dorsigera (SL $37.3 \mathrm{~mm}$ ) was collected with hand nets, during a field trip of a research project conducted by the Laboratório de Ecologia e Conservação de Ecossistemas Aquáticos, Universidade do Vale do Rio dos Sinos, aimed to know the biological diversity of wetlands in southern Brazil. The material was fixed in $10 \%$ formalin, later transferred into $70 \%$ ethanol, and deposited at Museu de Ciências e Tecnologia da Pontifícia Universidade Católica do Rio Grande do Sul, Porto Alegre (MCP 44511). Measurements were made with a digital caliper reading to the nearest $0.1 \mathrm{~mm}$.

The species was collected on October 13, 2002, in state of Rio Grande do Sul, southern Brazil, in small tributary floodplains of Uruguay River basin (Figure 2B). The site of occurrence of the species $\left(29^{\circ} 30^{\prime} 34.1^{\prime \prime} \mathrm{S}, 56^{\circ} 43^{\prime} 11.8^{\prime \prime} \mathrm{W}\right.$, $126 \mathrm{~m}$ above sea level) is a permanent palustrine wetland area, covered by dense macrophyte vegetation (Figure 3 ), located in municipality of Uruguaiana, district of João Arregui.

Although only one individual of $L$. dorsigera has been collected, it is unlikely that its occurrence in the Uruguay River Basin, state of Rio Grande do Sul, is due to the introduction for hobbyists or escapes from ornamental fish ponds. According to Roubach et al. (2003) southern Brazil differs from other regions of the country for its subtropical climate, and consequently the development of aquaculture is different. Unlike other regions where the ornamental tropical fish industry is developed (Roubach et al. 2003; Magalhães and Jacobi 2008), in southern Brazil, due to its lower average temperature, the fish culture is primarily based on obtaining animal protein through the cultivation of exotic fish 
species well adapted to the low winter water temperatures (Garcia et al. 2008; Baldisserotto 2009). Furthermore, among the records of invasive species in natural environments are not included in the species of ornamental fish (Garcia et al. 2004; Querol et al. 2005; Leal et al. 2009; Vitule 2009). Therefore we think that L. dorsigera occurs naturally in Rio Grande do Sul, and the fact that only one individual was found, seems to be attributed to the rarity of the species in the Uruguay River basin, and limitations of the sampling method used at study.

Finally this study extends the distribution of L.dorsigera, and is the first record of the species at Uruguay River basin and state of Rio Grande do Sul, southern Brazil. This record suggests that although the Uruguay River basin is relatively well known, there are still unexplored environments, where there may be species not yet reported, and found in other hydrographic systems, especially in the Paraná and Paraguay River drainages.
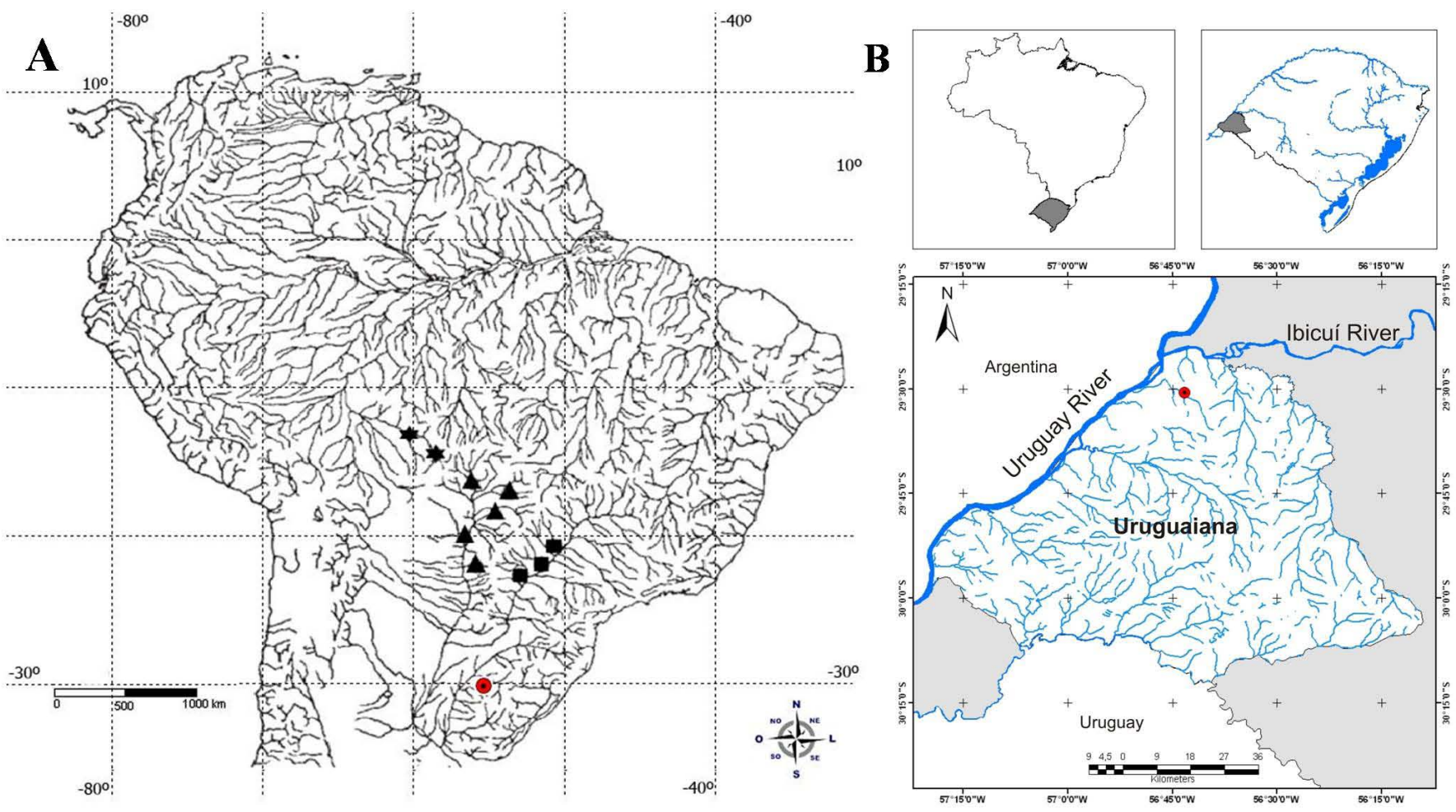

Figure 2. (A) Previous known distribution of Laetacara dorsigera including Amazon River basin, in the Guaporé River drainage $\mathbf{2}$; Paraná $\mathbf{\square}$ and Paraguay $\mathbf{\Delta}$ River basins, and the current record $\bigcirc$. Modified from Ottoni and Costa (2009). (B) Map detailing the occurrence of Laetacara dorsigera in small tributary floodplains of Uruguay River basin, municipality of Uruguaiana, state of Rio Grande do Sul, southern Brazil. Author: H. P. B. Neto. Source: Modified from Embrapa Monitoramento por Satélite (2005) and FEPAM (2005).

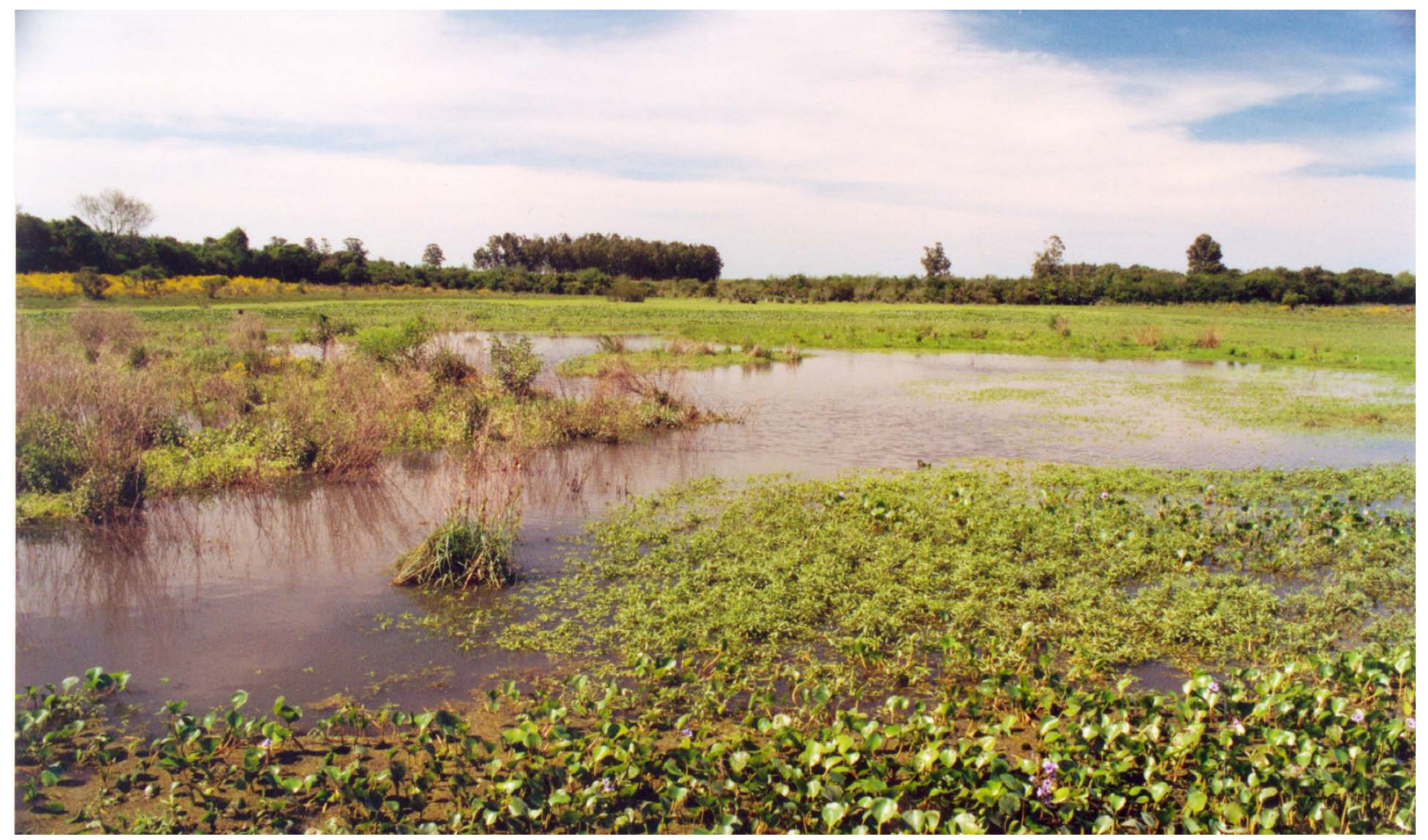

FIGURE 3. Sampling site of Laetacara dorsigera in Uruguay River floodplains, Rio Grande do Sul, southern Brazil. 
ACKNOWledgments: We thank Mr. Edison Martins dos Santos for the effort to capture the material, and Ms. Marina S. Dalzochio by editing the figures. This research was supported by funds from UNISINOS (02.00.023/00-0) and CNPq (52370695.2). Luis Esteban K. Lanés has scholarship masters of the CNPq and, Leonardo Maltchik holds a Brazilian Research Council - CNPq Research Productivity grant. This manuscript was improved by the comments of one anonymous reviewer.

\section{Literature Cited}

Baldisserotto, B. 2009. Freshwater fish culture in Rio Grande do Sul State: actual situation, problems and future perspectives. Ciência Rural 39(1): 291-299.

Casciotta, J.R. 1998. Cichlid-fishes from La Plata basin in Argentina: Laetacara dorsigera (Heckel), Bujurquina vittata (Heckel), and 'Cichlasoma' facetum (Jenyns) (Perciformes: Labroidei). Neotropica 44(111/112): 23-39.

Embrapa Monitoramento por Satélite. 2005. Sistemas Orbitais de Monitoramento e Gestão Territorial. Campinas: Embrapa Monitoramento por Satélite, 2005. Accessible at http://www.sat. cnpm.embrapa.br. Captured on 12 December 2009.

FEPAM. 2005. Fundação Estadual de Proteção Ambiental Henrique Luiz Roessler, RS. Biblioteca Digital. Arquivos digitais para uso em SIG. Base cartográfica Digital do RS 1:250.000. Accessible at http:// www.fepam.rs.gov.br/biblioteca/geo/bases_geo.asp. Captured on 12 December 2009.

Garcia, A.M., D. Loebmann, J.P. Vieira and M.A. Bemvenuti. 2004. First records of introduced carps (Teleostei, Cyprinidae) in the natural habitats of Mirim and Patos Lagoon estuary (South Brazil). Revista Brasileira de Zoologia 21(1): 157-159.

Garcia, L.O., C.E. Copatti, F. Wach holz, W. Pereira Filho and B. Baldisserotto. 2008. Freshwater temperature in the state of Rio Grande do Sul, Southern Brazil and its implication for fish culture. Neotropical Ichthyology 6(2): 275-281.

Kullander, S.O. 1986. Cichlid fishes of the Amazon River drainage of Peru. Stockholm: Swedish Museum of Natural History. 431 p.

Kullander, S.O. 1998. A phylogeny and classification of the South American Cichlidae (Teleostei: Perciformes); p. 461-498 In Malabarba, L.R., R.E. Reis, R.P. Vari, Z.M. Lucena, and C.A.S. Lucena (ed.). Phylogeny and Classification of Neotropical Fishes. Porto Alegre: Edipucrs.

Kullander, S.O. 2003. Family Cichlidae; p. 605-654. In R.E. Reis, S.O. Kullander and C.J. Ferraris Jr. (ed.). Checklist of the Freshwater Fishes of South and Central America. Porto Alegre: Edipucrs.

Leal, M. E., C.Q. Bremm and U. Schulz. 2009. Fish assemblage list of the Sinos river basin, south Brazil. Scientific Journal of Fisheries,
Aquaculture and Limnology 35(2): 307-317.

López-Fernández, H., K.O. Winemiller and R.L. Honeycutt. 2010. Multilocus Phylogeny and Rapid Radiations in Neotropical Cichlid Fishes (Perciformes: Cichlidae: Cichlinae). Molecular Phylogenetics and Evolution. in Press. Available online 21 February 2010 (doi:10.1016/j.ympev.2010.02.020).

Magalhães, A.L.B. and C.M. Jacobi. 2008. Ornamental exotic fish introduced into Atlantic Forest water bodies, Brazil. Neotropical Biology and Conservation 3(2): 73-77.

Musilová, Z., O. Říčan, K. Janko, and J. Novák. 2008. Molecular phylogeny and biogeography of the Neotropical cichlid fish tribe Cichlasomatini (Teleostei: Cichlidae: Cichlasomatinae). Molecular Phylogenetics and Evolution 46(2): 659-672.

Ottoni, F.P. and W.J.E.M. Costa. 2009. Description of a new species of Laetacara Kullander, 1986 from central Brazil and re-description of Laetacara dorsigera (Heckel, 1840) (Labroidei: Cichlidae: Cichlasomatinae). Vertebrate Zoology 59(1): 41-48.

Ottoni, F.P., J.L. de O. Mattos and I. Schindler. 2009. Re-description of Laetacara curviceps (Teleostei: Cichlidae: Cichlinae). Vertebrate Zoology 59(2): 123-129.

Querol, M.V.M., E. Querol, E.F.C. Pessano and C. Azevedo. 2005. Ocorrência da carpa húngara, Cyprinus carpio (Linnaeus, 1758) e disseminação parasitária, no arroio Felizardo, Bacia do médio rio Uruguai, Uruguaiana, RS, Brasil. Biodiversidade Pampeana, Uruguaiana 3: 21 23.

Roubach, R., E.S. Correia, S. Zaiden, R.C. Martino and R.O. Cavalli. 2003. Aquaculture in Brazil. World Aquaculture, Baton Rouge, Louisiana 34(1) 28-34.

Smith, W.L., P. Chakrabarty and J.S. Sparks. 2008. Phylogeny, taxonomy, and evolution of Neotropical cichlids (Teleostei: Cichlidae: Cichlinae). Cladistics 24 625-641.

Staeck, W. and I. Schindler. 2007. Description of Laetacara fulvipinnis sp. n. (Teleostei: Cichlidae) from the upper drainages of rio Orinoco and rio Negro in Venezuela. Vertebrate Zoology 57(1): 63-71.

Vitule, J.R.S. 2009. Introduction of fishes in Brazilian continental ecosystems: Review, comments and suggestions for actions against the almost invisible enemy. Neotropical Biology and Conservation 4(2): 111-122.

RECEIVED: January 2010

REVISED: February 2010

ACCEPTED: March 2010

Published ONLINE: March 2010

EDITORIAL RESPONSIBILITY: Javier A. Maldonado O. 